\section{Catch 22}

WE don't often comment editorially on the stories of Sovict policy towards dissidents that we carry with monotonous regularity. This is not because we don't believe them -it's because they have a peculiar eloquence of their own to which cosy editorialising from a London office can add little. Sufficient it is that scientists should be aware on a worldwide basis of what goes on and act accordingly. The same goes for the testimony of Vladimir Bukovskii on the following page. But one story emerging from Moscow so confounded our sense of logic that we feel it deserves a little comment.

Academician Veniamin Levich was briefly taken into custody on December 21 as part of a new campaign against participation in the unofficial scientific seminars for dismissed scientists. He was referred to a TASS statement of November 9 concerning the Soviet position on emigration. Since this provoked no overseas reactions, he was told, this must imply tacit agreement.

The unattributed statement, one of many issued on or around Revolution Day, was broadcast in English at 07.36 and ran, in part, "each request from an individual citizen to be allowed to go and live in another country in order to reunite split families is given full consideration. Refusals are made in an insignificant number of cases, when the citizen expressing the wish to leave the USSR has had access in the course of his duties to works or information that represent a state secret ..."

Since "the secrets of a state are always its own exclusive property", it went on, "it is an internal question for the Soviet Union to decide which specific works or information are to be considered secret, obsolete, or to have lost importance in guaranteeing the defences and other important national interests of the USSR". Accordingly, "any attempt at pressuring competent Soviet organisations into changing their position is considered an interference in the domest'c affairs of the USSR. As for the big antiSoviet noise raised in the West, it pursues the sole aim of misleading public opinion . . Bourgeois propaganda is doing everything it can to distract attention from the systematic and gross violations of basic human rights in capitalist society".

In view of the strong hints that a big anti-Soviet noise is an interference in the domestic affairs of the USSR it is somewhat remarkable that the said "competent Soviet authorities" now quote the lack of "noise raised in the West" as a justification for their policy.

\title{
No export potential in steam tape-recorders
}

"PARLEZ-VOUS electric?", runs a recent large advertisement by the UK Electricity Council in national newspapers, at a cost of goodness-knows-how-many-thousand pounds. "There are thousands of tape-recorders with headsets in use in UK schools. Thousands more are used each year by executives of multi-national companies on six-week intensive courses in a foreign language. Headsets. Video tape-recording equipment. Magnetic tape. All these modern educational aids are powered by electricity. The child learns his language idiomatically. So do the men. Men responsible for earning this country millions of pounds in export orders from foreign countries. Exports are this country's life blood. Electricity helps generate them. Think Electric",

"Look here, Blenkinsop," said the Minister for Energy, the moment the Director of the Electric Power Generating Board had sat down. Blenkinsop knew immediately that this was to be the dreaded eyeball-to-eyeball confrontation. He fumbled for his pipe. "I'm getting fed up with the way everyone else in the Cabinet is talking about export, export all the time-boasting about their departments' achievements-and we're still importing in our department. I get a lot of stick for it, so you'd better get your advertising copywriters to do something about brushing up our image. There must be something we export. Oh, and also", Blenkinsop shifted uneasily, "I've been looking at electric consumption figures for these last few weeks. What's going on? We're $5 \%$ down on last year, and I've got all these boilermakers, miners, nuclear engineers and what-have-you on my back about building more power stations. I want you to get out and stimulate consumption in a really big way. Find something which really soaks up electricity and push it hard." "Yes, sir" said Blenkinsop. The minister pulled a drawer open. Blenkinsop wondered if it was to be a letter asking for his resignation. But no; the minister decanted three or four small boxes on the table.

"Know what these are?" "No, sir". "Really, Blenkinsop, you're not very alert to the opposition. They are tape recorders-but they don't run on electricity. This is a clockwork one - it punches a tiny paper tape. It's made in Switzerland by all those watchmakers put out of business by digital watches. It sounds a bit like a 78-record, I admit, but you see how they'll develop it. This one's made in France. It runs on lighter-fuel, and I hardly need remind you that North Sea oil doesn't yield lighter-fuel so it'll have to be imported. And this one is made by our own dear old Gas Board; that's a shot across your bows, isn't it, Blenkinsop? Now you get people cracking; they've three big campaigns to do on export, consumption and competition".

"Yes, sir", said Blenkinsop, as his civil-servant brain swung into action "but, sir, if I can save us money with some sort of integrated campaign, do you thing I might, er . . . er . . . be so bold as to have a Permanent Secretary's $10^{\prime} 9^{\prime \prime} \times 7^{\prime} 3^{\prime \prime}$ thick-pile carpet for my office? I only really qualify for the Deputy Secretary's $8^{\prime} 3^{\prime \prime} \times 6^{\prime} 4^{\prime \prime}$ rug".

"Oh, very well" said the minister, irritably, and out trooped a gleeful Blenkinsop. "Odd people, these civil servants," mused the minister, "I wonder what he meant by an integrated approach ... I hope he doesn't make a fool of us". 